\title{
Interactive comment on "Hydrologic modeling of a Himalayan mountain basin by using the SWAT mode" by Sharad K. Jain et al.
}

\section{E. Bardsley}

web@waikato.ac.nz

Received and published: 23 April 2017

Just a very brief comment. The study location has a high degree of seasonality, so presumably the NSE values for monthly data were calculated using the discharge means for each individual month, otherwise the values will be artificially high. Perhaps the paper could include the expression used to calculate the NSE values for the monthly discharge data.

Interactive comment on Hydrol. Earth Syst. Sci. Discuss., doi:10.5194/hess-2017-100, 2017. 